\title{
o direito à subsistência em xeque: um olhar sobre a lei dos pobres e o ato de emenda de $1834^{\star}$
}

\author{
the right to subsistence in check: a look upon \\ the poor laws and the amendment act of 1834
}

\author{
Daniel Schneider Bastos $\star \star$ \\ Instituto de Ciências Humanas e Filosofia, Universidade Federal Fluminense, Niterói, Rio de \\ Janeiro, Brasil
}

\begin{abstract}
ReSUmo
O estudo analisa a Lei dos Pobres como uma questão de debate socioeconômico na Inglaterra, durante a Revolução Industrial, destacando a campanha de difamação movida contra essa instituição, que culminou com o Ato de Emenda de 1834 e a criação da Nova Lei dos Pobres. Entende-se que esse movimento representa um marco importante para a emergência de um programa político próprio dos setores ligados à economia industrializada. Ainda que não se tratasse de um projeto acabado, é possível identificar, a partir da década de 1830, o fortalecimento de argumentos que, assentados sobre a defesa do livre mercado, propunham uma reordenação estrutural da sociedade que favorecesse a acumulação de capital industrial, sendo a reforma das práticas de socorro aos pobres uma bandeira importante nesse sentido.
\end{abstract}

Palavras-chave: Revolução Industrial. Lei dos Pobres. Inglaterra. Economia política.

\begin{abstract}
The study analyzes the Poor Laws as a question of socioeconomic debate in England during the Industrial Revolution, highlighting the defamation campaign moved against this institution, culminating with the Amendment Act of 1834 and the creation of the New Poor Law. It's understood that this movement represents a important landmark to the emergence of a own political program of the sectors linked to the industrialized economy. Although it wasn't a finished project, it's possible to identify from the 1830s the strengthening of arguments that, seated on the defence of the free market, proposed a structural reordering of society that would favoured the accumulation of industrial capital, being the reform of the poor relief practices a important banner in this sense.
\end{abstract}

Keywords: Industrial Revolution. Poor Laws. England. Political economy.

* Submetido: 11 de outubro de 2017; aceito: 20 de fevereiro de 2018.

$\star \star$ Mestre em História pela Universidade Federal Fluminense. E-mail: danielbastos@, id.uff.br 


\section{Introdução}

Diante de uma nova conjuntura de crise econômica global iniciada há cerca de dez anos, que veio a agravar a pressão exercida tanto no mundo desenvolvido, quanto nas economias em desenvolvimento sobre as políticas sociais e o bem-estar social, é pertinente lançar um olhar ao passado para o momento em que o tema do auxílio aos pobres e do direito à subsistência, na condição de políticas públicas nacionais, esteve em pauta como um debate prioritário pela primeira vez. Essa recapitulação nos traz de volta à questão da Lei dos Pobres inglesa, o primeiro código nacional de legislações com essa finalidade. Baseada no princípio de que era encargo das administrações paroquiais zelarem por seus pobres desamparados, empregando os sadios e subsidiando a subsistência dos inválidos para o trabalho, a Lei dos Pobres, instituída no início do século XVII, passa a conviver com ataques permanentes contra seu funcionamento a partir do século XVIII, quando o gasto público que ela representa entra em uma espiral ascendente. A gestão dos desamparados converteu-se cedo em uma problemática central para o pensamento econômico britânico, inclusive para a jovem economia política. Para além de envolver questões relativas à própria natureza humana, estava em jogo a disputa entre uma ordem capitalista industrial emergente e um capitalismo fundiário mais antigo, que mantinham interesses antagônicos quanto à administração do pauperismo na ilha. A campanha negativa contra o assistencialismo culminou em 1834, com o Ato de Emenda, que, sob o pretexto da austeridade das contas públicas e da moralização dos pobres, instituiu uma legislação muito mais baseada na vigilância, na internação e no controle social dos pobres, conhecida como a Nova Lei dos Pobres.

$\mathrm{O}$ artigo se inicia com uma reconstituição do surgimento e estruturação da Lei dos Pobres como um sistema organizado até o século XVIII, comentando sobre algumas das polêmicas historiográficas referentes a esse período inicial. Em seguida, discute a forma como esse sistema é representado nos trabalhos que abordam a economia política entre as últimas décadas do século XVIII e o começo do século XIX. Daí se passa para a questão da reforma de 1834, dentro do entendimento de que a Nova Lei dos Pobres pode ser encarada como um marco na Inglaterra, rumo ao desenvolvimento de um programa político de viés totalizante atrelado ao interesse do capital industrial. Embora deva ser 
admitido que a estruturação da burguesia industrialista como classe não era um fenômeno perfeitamente consumado, de sorte que não se encontra, ao menos até 1838 , uma associação que reivindique com maior clareza essa identidade e que atue no sentido de representar publicamente suas aspirações, é possível identificar a partir de 1832 um conjunto de iniciativas que favorece esse setor. Por meio de reformas legislativas e da construção de um discurso pautado na representação da grande indústria e do livre mercado como mecanismos primordiais de desenvolvimento econômico e social, propõem-se transformações estruturais que visam orientar a sociedade inglesa nessa direção, o que incluía a reforma da Lei dos Pobres. Dessa forma, a pressão política em prol da instituição da Nova Lei dos Pobres pode ser compreendida como uma das etapas no processo de amadurecimento da burguesia industrialista na condição de classe dirigente, isto é, ampliar sua capacidade de alocar seus interesses dentro da estrutura do pacto de dominação firmado havia muito tempo com a nobreza, cuja riqueza advinha fundamentalmente de suas posses fundiárias. Para além da reforma das práticas assistencialistas em si, as diretrizes estabelecidas como norteadoras dessa iniciativa serviram como elemento de convergência de ideias de uma intelectualidade de classe média, mais identificada com um projeto de industrialização que contemplava a sociedade em sua totalidade. $\mathrm{Na}$ ausência de mecanismos e órgãos de classe plenamente formados, essas referências tiveram papel decisivo para fornecer à Revolução Industrial a base política necessária para consolidar seu desenvolvimento em direção a se afirmar como novo paradigma de organização social da vida e do trabalho.

\section{A Lei dos Pobres antes do século XVIII}

$\mathrm{Na}$ Europa Ocidental como um todo, as Monarquias medievais começaram a intervir mais efetivamente sobre a pobreza com as dramáticas mudanças sociais impostas pela chegada da peste no século XIV. Até então, a tradição era que esse assunto fosse regulado pela relação direta entre os pobres com o clero ou a nobreza, com pouca intervenção das Coroas. A Inglaterra não foi uma exceção nesse sentido. Eduardo III viu-se obrigado durante seu reinado a instituir a Ordenança dos Trabalhadores em 1349, que decretou a obrigação de trabalhar para todos os 
que fossem considerados sadios para tal. Dois anos depois um novo estatuto teve de ser aprovado pelo Parlamento, reafirmando a necessidade do trabalho e decretando que os trabalhadores deveriam aceitar salários nos patamares anteriores à pestilência. Legislações mais repressivas foram adotadas para coibir a circulação de vadios, uma categoria extensa que podia abarcar desde mendigos famintos a soldados desmobilizados (Geremek, 1986, p. 100-103). Nesse quesito, pouca coisa distinguia a ilha do continente, no que diz respeito às estratégias adotadas pelo governo para lidar com uma nova realidade socioeconômica.

Com os governos da dinastia dos Tudor (1485-1603), a Coroa inglesa passou a assumir papel crescente no estabelecimento das diretrizes para a gestão da pobreza. O século XVI é marcado pela multiplicação de um novo tipo de pobre que não se enquadrava na concepção eclesiástica dos períodos passados, dividida entre as figuras dos merecedores (os incapacitados para o trabalho e que eram, por isso, dignos de caridade) e os vagabundos (os que optavam pela vida viciosa). O regime Tudor deparava-se agora com o trabalhador desempregado ou subempregado, gente apta e ávida por trabalhar em troca do próprio sustento, mas incapaz de encontrar oportunidades para fazê-lo. Essa categoria já existia no medievo e cresceu com o colapso da ordem feudal na Inglaterra, que se inicia com a peste, tornando-se cada vez mais comum graças às mudanças nas relações econômicas rurais que caracterizam a transição do feudalismo para o capitalismo agrário.

Desde fins do medievo, após as passagens mais catastróficas da peste pela ilha nos séculos XIV e XV, uma nova conjuntura tendeu a elevar continuamente o preço da terra inglesa ao longo de toda a Idade Moderna até a Revolução Industrial. Esse encarecimento está relacionado à combinação de um aumento populacional persistente, que se observa desde o século XVI, juntamente com a alternância de períodos de valorização da lã e dos cereais. É nesse contexto que o fenômeno dos cercamentos irá se proliferar, isto é, os processos nos quais proprietários de terra reorganizavam suas posses fundiárias com a finalidade de aumentar seu valor. Para tal, agrupavam pequenos arrendamentos em fazendas maiores e repartiam entre elas terrenos que até então constituíam espaços comunais ou campos abertos ${ }^{1}$. As novas fazendas tinham suas

1 Por espaços comunais, refiro-me de forma genérica aos espaços não cultivados que 
fronteiras cercadas como forma de delimitar com clareza a divisão entre elas e coibir a entrada dos camponeses destituídos de acesso formal a esses espaços. O primeiro surto de cercamentos se situa entre o final do século XV e o começo do XVI, com o incentivo de converter terra de má qualidade para o cultivo de cereais em pasto para as ovelhas, abastecendo a próspera manufatura doméstica de tecidos de lã. Conforme a lã se desvalorizou em relação a outros produtos agrícolas no decorrer do século XVI, o cercamento freou seu ímpeto por algumas décadas, mas o crescimento demográfico manteve a tendência de elevação do preço da terra, dificultando cada vez mais a manutenção do acesso direto a ela pelas famílias de pequenos arrendatários. Ao número crescente de trabalhadores que perdiam seus direitos de posse ou que os mantinham em grau insuficiente para assegurar uma subsistência autônoma, restava buscar empregarem-se como assalariados para a minoria de fazendeiros que apresentava melhor sorte na condução dos negócios (Patriquin, 2007, p. 56-59).

Coube às Monarquias Tudor do século XVI a busca por estabelecer um sistema que lidasse com esse novo pauperismo, com medidas que fossem além da simples coibição à vadiagem. Dezenas de estatutos ao longo do século XVI se encarregaram de definir as paróquias como unidades administrativas autônomas, no que diz respeito à prestação de socorro aos pobres, conferindo às autoridades locais poderes para coletar impostos compulsórios entre os proprietários paroquianos com a finalidade de financiar essas atividades. A Coroa encontrava assim um modo de poupar seus próprios recursos e passar os custos para as localidades. O estabelecimento dessa rede de caridade não dispensou, todavia, o lado coercitivo da legislação: pobres que se recusassem a se estabelecer em uma paróquia, tornando-se vadios, ou mendigassem sem autorização, estavam sujeitos a castigos fisicos, que podiam envolver açoites, mutilação das orelhas ou mesmo a forca para os reincidentes. As diretrizes principais desses estatutos foram compiladas ao fim do período elisabetano.

eram reivindicados pelos camponeses como áreas de exploração aberta aos integrantes da localidade, tais como bosques, terrenos balidos, florestas, pântanos etc., de onde se extraía uma variedade de recursos importantes para a subsistência camponesa. $\mathrm{O}$ sistema de campo aberto, por sua vez, é algo mais específico, difundido na Inglaterra, nos séculos XII e XIII, no qual os senhores disponibilizam parte da terra arável para uso dos camponeses, geralmente como pastagem. 
Em 1601 estava completa a Lei dos Pobres, como ficou conhecido o código que passava a orientar oficialmente toda a gestão pública em relação aos pobres. Essa legislação sofreria poucos adendos antes do século XIX. O principal foi o Ato de Assentamento de 1662, que decretou que apenas os pobres devidamente "assentados" em uma paróquia poderiam ser socorridos por ela.A condição de assentado era obtida por nascimento na paróquia, matrimônio com um paroquiano ou ao se residir por lá durante um período preestabelecido de tempo. Seu objetivo era evitar que multidões empobrecidas vagassem rumo às paróquias mais ricas em busca de auxílio.

O século XVII parece ter testemunhado uma retomada do avanço dos cercamentos, assim como a disseminação de novas relações entre a aristocracia de proprietários rurais e os arrendatários que exploravam suas terras. Modelos de concessão de uso da terra que ofereciam maior estabilidade para o arrendatário vão sendo substituídos pelo leaseholding, no qual se pagava um preço ao proprietário não mais definido pelo costume, mas pela competição. O leaseholding era o modelo no qual a renovação do termo de posse estava condicionada à capacidade do ocupante de fazer o máximo de uso produtivo desta, incentivando a competição entre os inquilinos. Esse já era o sistema de arrendamento predominante no começo do século XVIII. Têm-se então um movimento duplo de expropriação, em que, por um lado, a terra cultivável encarece pela competição e torna-se cada vez mais acessível apenas para fazendeiros mais ricos, enquanto simultaneamente terrenos não cultivados ou de uso comum, importantes para a subsistência, são cercados por conta da elevação do preço da propriedade fundiária (Patriquin, 2007 , p. 49-56). Os yeomen, uma categoria abrangente empregada para designar pequenos camponeses que possuíam uma quantidade razoável de terra, cultivando-a diretamente, já estavam em vias de extinção no século XVIII. Quando, a partir de 1760, se inicia uma extensa temporada de cercamentos, dessa vez movida predominantemente por atos parlamentares, relativamente poucos terrenos comunais restavam para ser expropriados, e virtualmente já não se poderia mais falar na existência de uma classe camponesa em sentido clássico, mas, sim, de uma grande massa de assalariados rurais.

É altamente discutível o papel que a Lei dos Pobres veio a desempenhar na prática, especialmente no século XVII. Interpretações que 
reivindicam a existência de uma "particularidade inglesa", referente à maneira precoce com as quais as relações capitalistas agrárias teriam emergido e se consolidado na Inglaterra com relação à Europa, como se observa de modo notável entre historiadores de influência marxista, parecem inclinadas a considerar o sistema paroquial como uma entidade de forte impacto na vida dos ingleses comuns ainda no século XVII. Seguindo a explicação de Patriquin (2007), que toma como pressuposto a estrutura de capitalismo agrário na Inglaterra desenhada na obra clássica de Wood (2001) sobre o aparecimento desse modo de produção, a Lei dos Pobres se apresentou como uma necessidade para viabilizar a transição para a nova ordem econômica, assegurando um mínimo de compensação aos camponeses que perdiam o acesso direto a terra e ficavam reféns das flutuações do mercado de trabalho. Durante séculos, a Inglaterra teria desfrutado de um sistema único tanto por sua abrangência nacional, quanto por sua relativa eficiência, de sorte que, apenas na segunda metade do século XIX, outras nações europeias que enfim passavam pelo processo de expropriação massiva da pequena posse fundiária camponesa adotariam modelos comparáveis. Essa explicação encontra-se em sintonia com o conceito marxista de acumulação original (Marx, 2015, p. 506-541), utilizado para conceber o longo processo que iria culminar com o capitalismo industrializado que ascendeu com a Revolução Industrial, dando-se grande ênfase à formação de um "proletariado rural" inglês muito mais cedo do que em qualquer outra parte do globo.

Essa visão vem sendo fortemente criticada por autores que entendem que a Lei dos Pobres representou, ao menos durante seu primeiro século de existência formal, mais um referencial teórico do que uma realidade concreta. Partindo do princípio de que as pequenas economias paroquianas eram frágeis demais para socorrer devidamente a grande quantidade de indivíduos que lutavam para se equilibrar sobre a linha que divide a miséria da subsistência, autores como King (2003) e Hindle (2004) desacreditam a ideia de que a Lei dos Pobres construiu de fato um sistema nacional abrangente de caridade pública no decorrer do século XVII, ou mesmo mais adiante. Enfatizam que os estatutos, embora compelissem os proprietários locais a ajudar seus pobres, não decretavam padrões uniformes para essa administração, que fica ao arbítrio das autoridades locais. Chamam a atenção para o fato de que uma 
parcela diminuta dos pobres era abonada pelo Tesouro paroquial, de modo que a sobrevivência para a maioria dependia da habilidade do indivíduo para trafegar dentro de uma rede complexa de recursos, que incluía a caridade laica ou eclesiástica, a ajuda de parentes ou vizinhos, a exploração de terrenos como bosques, florestas, terrenos baldios, pastagens, ou mesmo o crime, como última alternativa. Essa teia delicada constituía aquilo que Hindle (2004, p. 47-48) denominou "economia de recursos diversificados". Na medida em que os cercamentos privavam crescentemente os camponeses do acesso a esses espaços não cultivados, que representavam uma parte fundamental dessa estratégia de subsistência, a pressão sobre as paróquias aumentou. Parece certo que no século XVIII elas estavam mais bem organizadas em relação ao passado para exercer um papel maior de amparo à pobreza, ainda que com eficiência discutível. Diante dessas perspectivas, o modelo inglês, no que diz respeito ao seu impacto real sobre a pobreza, não teria diferido tanto, até o fim do século XVII ao menos, de outros sistemas de caridade que existiram pela Europa.

Sem negar o peso da economia de recursos diversificados para a sobrevivência dos humildes, Charlesworth (2010), questiona esse tipo de posicionamento que rebaixa a Lei dos Pobres a um mero conjunto de referências teóricas, salientando que se tratava de uma legislação de fato, amparada pela vigorosa rede de juízes que compunha a common law inglesa. Tratava-se de uma instituição que se mostrou forte o suficiente para permanecer sendo respeitada mesmo através dos períodos mais conturbados do século XVII, quando a autoridade central era incerta. Charlesworth aponta para uma vasta quantidade de registros existentes de pobres apelando aos poderes locais para reivindicarem auxílio, o que seria um indicativo de que, na consciência popular, o princípio da garantia da subsistência para os necessitados era entendido como um direito real. O caráter prático da Lei dos Pobres, sobretudo em seus primeiros momentos, permanece uma questão em aberto, na qual o autor deste artigo se vê inapto para emitir conclusões. Comentarei apenas que, caso a corrente que enxerga na caridade paroquial uma instituição de menor relevância almeje confirmar-se como nova ortodoxia, tem pela frente o trabalho de desenvolver explicações para a transição para a economia capitalista que estejam mais bem harmonizadas com essa posição secundária da Lei dos Pobres. De todo modo, é uma questão atual na historiografia, na qual há grande espaço para novos trabalhos. 
É seguro, contudo, considerar que a Lei dos Pobres se tornou mais estruturada no século XVIII, e que, no último terço deste, ela era uma realidade bastante palpável para os pobres, sobretudo em condados rurais do leste e do sul. A partir desse recorte, está fora de dúvida de que esta desempenhava um papel econômico importante associado às relações de mercado e trabalho capitalistas, nessa altura certamente muito mais avançadas na Inglaterra, do que entre os demais Estados europeus. É justamente nesse momento que o tópico da Lei dos Pobres começará a angariar críticas mais pesadas e consistirá em um tema de debate importante para correntes que emergem com o campo nascente da economia política.

\section{Críticas à Lei dos Pobres com o aparecimento da economia política}

Sob o domínio Tudor, época em que o pensamento humanista se fortalece no reino, observavam-se sinais de que a passagem para uma abordagem laica do problema da pobreza seria acompanhada por uma concepção pessimista sobre as inclinações dos pobres. Juan Luis Vives, acadêmico de origem espanhola que viveu alguns anos na Inglaterra e frequentou a Corte de Henrique VIII, foi responsável pela autoria do mais influente trabalho sobre o tema do século XVI, De subventione pauperum, de 1526 . Nele, Vives defendeu que o pauperismo se tornasse majoritariamente uma questão do Estado, ao mesmo tempo em que alertava para o que considerava como traços naturais do caráter dos humildes, que os direcionavam no sentido da preguiça e da apatia. Entretanto, como os demais humanistas, tinha convicção de que esses vícios poderiam ser corrigidos pela disciplina e boa conduta, não excluindo dessa forma os pobres como indivíduos sujeitos ao aprimoramento, como os demais seres humanos. O trabalho era uma ferramenta fundamental para tal, por issoVives instruiu as autoridades a nunca oferecerem caridade aos aptos para a labuta (Beier, 2004, p. 16-19). Essa orientação era abraçada pelos Tudor.A Lei dos Pobres herdou dos estatutos passados a diretriz para que os sadios fossem contemplados com ajuda paroquial apenas em troca de trabalho arranjado pelas autoridades ou por empregadores locais. $\mathrm{Na}$ prática, isso era inconveniente e sobrecarregava os 
poderes locais, sendo mais comum oferecer ao necessitado uma soma financeira modesta sem exigir serviço em troca. Também era bastante difundido o hábito de cederem-se roupas, serviços médicos, pagamento de aluguéis, alimentos e outros benefícios que se enquadravam na categoria de "ajuda extramuros", isto é, o socorro concedido fora de instituições desenhadas para tal.

Uma hostilidade maior contra o sistema começa a ser observada apenas no século XVIII. Especialmente em seu último terço, esse século testemunhou grande aumento nas despesas representadas pelos pobres, momento em que começam a ecoar críticas explícitas ao sistema. Mas alguns argumentos que embasam essa postura podem ser encontrados, ainda que indiretamente, em trabalhos anteriores a esse período. $\mathrm{O}$ exemplo mais importante é a obra do filósofo anglo-holandês Bernard Mandeville (1962). Em 1714, com a publicação do livro $A$ fábula das abelhas, o autor defendeu que o vício privado se convertia no bem coletivo, com argumentos que antecipavam em meio século alguns dos principais pontos levantados por Smith em $A$ riqueza das nações. Mandeville entendia que mesmo a postura considerada socialmente virtuosa está embasada em sentimentos como a vaidade ou a inveja, dado que a motivação do indivíduo ao praticar ações altruístas era primeiramente seu orgulho próprio, e que não poderia haver prosperidade em uma sociedade sem a avareza ou a cobiça. As paixões humanas não deveriam ser sufocadas, mas abraçadas, visando ao benefício comum, cabendo à boa política zelar pela condução dessa energia, visando às causas positivas, ainda que não tenha sido capaz de explicar de que maneira essa gestão deveria se dar. O importante é observar que, se por um lado os indivíduos são investidos de uma natureza egoísta comum, por outro, o modo como lidam com essa natureza é socialmente diferenciado. Para a gente sofisticada, que cultivara os hábitos refinados e a instrução intelectual, o impulso perverso convertia-se em combustível para o engrandecimento pessoal, motivado pela busca do reconhecimento alheio. Quanto aos humildes, cujas origens e perspectivas de vida impediam que desenvolvessem grandes ambições, não era de esperar que esse mesmo impulso fosse direcionado para a industriosidade, visto que sua condição não combinava com maiores aspirações. Sabiam mirar apenas as recompensas mais imediatas, entregando-se aos prazeres devassos tão logo sentissem suas necessidades primárias satisfeitas. $\mathrm{O}$ efeito positivo que o orgulho 
exercia sobre as classes privilegiadas só seria alcançado nos pobres pelo desespero da miséria e da fome, porque estes não tinham uma vaidade bem cultivada. Justificava-se assim o pagamento de salários de subsistência (Mandeville, 1962, p. 123).

A crueza com a qual Mandeville expôs seu pensamento rendeu-lhe críticas muito efusivas, mas ele plantou algumas sementes que germinarão mais tardiamente no século XVIII, quando a insatisfação com a Lei dos Pobres aumentará muito. Estima-se que, ao fim do século XVII, o gasto total com a ajuda paroquial em todo o reino estava na faixa de $400 \mathrm{mil}$ libras anuais, e que esse valor se situava em quase 700 mil por ano entre 1748 e 1750 . Entre 1783 e 1785 o número dispara para 2 milhões anuais, mostrando inquestionável aceleração do ritmo das despesas (Boyer, 2002). Essa inflação fermentou, sobretudo nas cidades, o ódio de grande parte dos contribuintes, em sua maioria pequenos proprietários de classe média. Isso deixou profundas impressões na ampla gama de reflexões que compunham a economia política, jovem área do conhecimento que se propunha a definir as práticas apropriadas para o bom governo e a boa gestão da riqueza em um mundo que visivelmente passava por transformações importantes. O tema será abordado por esses autores de modo não homogêneo. Smith (2007), por exemplo, conseguiu embasar sua crítica ao assistencialismo fora de um determinismo pessimista quanto à natureza humana, fato notável diante do negativismo com o qual a filosofia do século XVIII revestiu esse objeto. Embora em $A$ riqueza das nações, de 1776, tenha exaltado o egoísmo humano como força motriz do progresso material, resgatando ideais de Mandeville, o filósofo e economista escocês não seguiu pelo caminho de seu predecessor quanto a distinguir tendências divergentes na forma como ricos e pobres expressavam sua natureza autocentrada.Ao contrário, reconheceu em todos os homens a existência de um desejo por prosperidade, que se manifestava entre os trabalhadores pela prontidão em abraçar avanços que elevassem sua produtividade e, consequentemente, seus salários. O uso positivo do interesse pessoal (sendo "interesse" um termo muito mais palatável do que "vício", como Mandeville aplicara anteriormente) estava ao alcance de todos e não representava mais um privilégio elitista (Himmelfarb, 1988, p. 60-79). Mas, para que esse potencial comum a todos fosse aproveitado, era necessário que o mercado atuasse com liberdade, e a Lei dos Pobres aparecia entre as intervenções 
arbitrárias que atravancavam o funcionamento do laissez-faire. Para Smith (2007, p. 111-116), o principal problema era o Ato de Assentamento, que em sua visão impedia a livre circulação de mão de obra, prendendo trabalho ocioso em paróquias onde não havia utilidade para ele e impedindo que este escorresse para onde havia demanda.

A repercussão das ideias de Smith após a publicação de sua obra magna foi, como se sabe, imediata. Seu legado foi apropriado de modo heterogêneo por aqueles que o sucederam nos estudos da economia política. A defesa da não intervenção (ou, melhor dizendo, intervenção moderada) do Estado nos assuntos econômicos privados, conceito que levaria Smith a ser reconhecido como maior expoente daquilo que viria a ser chamado de liberalismo, ecoou em autores que preferiam desacoplar esse conceito com o relativo otimismo de Smith com relação aos indivíduos, notadamente em se tratando dos mais pobres. Apenas dez anos depois da primeira edição de $A$ riqueza das nações, a publicação do tratado do reverendo Joseph Townsend, intitulado Uma dissertação sobre a Lei dos Pobres, voltou a reforçar a ideia de que grandes contingentes populacionais estariam sempre, em qualquer parte, fadados à vida dificil e aos mais indesejados serviços. Fazia parte da ordem natural que essa gente, inclinada por sua condição para a imprevidência e falta de perspectiva, existisse para prestar as tarefas que seriam inapropriadas para os indivíduos de melhores estratos, que não eram tolhidos para a labuta e os oficios perigosos:

Parece ser uma lei da natureza que o pobre deva ser em certa medida imprevidente, que deva haver sempre alguém para preencher os mais abjetos, os mais sórdidos e os mais ignóbeis ofícios na comunidade. O estoque de felicidade humana é dessa forma muito aumentado, enquanto os mais delicados são não apenas aliviados da labuta, e libertos desses empregos casuais que fariam deles miseráveis, mas são deixados à liberdade, sem interrupção, para perseguir aquelas vocações que são apropriadas às suas várias inclinações, e mais úteis ao país. Quanto aos mais baixos entre os pobres, por costume eles estão conciliados com as mais desprezíveis ocupações, aos trabalhos mais laboriosos e às carreiras mais perigosas, enquanto a expectativa de sua recompensa faz deles alegres em meio a todos os perigos e trabalho duro. (Townsend, 1817, p. 39) 
Por seu perfil embrutecido, as camadas mais desfavorecidas da população encontravam a felicidade por meio do trabalho e do retorno imediato do fruto de seu suor. Seu incentivo principal, portanto, é a necessidade constante. A Lei dos Pobres, ao transformar a subsistência em um direito, e não mais algo a ser conquistado pela labuta, esvaziava esse fundamento, sobre o qual estava estruturada a ordem social. "Ele, que prontamente emprega o pobre em trabalho útil, é seu único amigo; ele, que apenas o alimenta, é seu maior inimigo" (Townsend, 1817, p. 19-20), sintetiza em suas considerações. O único modo sustentável de se socorrer os pobres era por via da doutrina do trabalho. Sugeriu que oficinas fossem montadas pelas paróquias onde os desamparados pudessem ter acesso aos materiais para trabalhar, sem receber abrigo ou comida por isso, pois estes deveriam ser adquiridos com o resultado da labuta. Como característico das primeiras décadas da economia política, a argumentação combina um cientificismo com pareceres morais sem que haja uma separação tão clara entre ambos. Isso é muito bem exemplificado, quando Townsend (1817, p. 42-46) recorre ao exemplo supostamente verdadeiro de uma ilha na qual os espanhóis haviam introduzido um casal de cabras para criação. A abundância de pasto e ausência de predadores fez com que a população de caprinos se multiplicasse exponencialmente, até se esgotar o alimento e se iniciarem ciclos de alta mortalidade. Foi preciso que cães caçadores fossem trazidos para estabilizar a situação, permitindo que apenas as cabras aptas e esforçadas sobrevivessem no novo ambiente. Estabelece-se um paralelo entre a economia e a natureza para conferir ao argumento uma aura de ciência naturalista, quando o cerne do discurso é uma colocação moralista: a fome e a morte são o castigo justo para a preguiça, e apenas tragédia social poderia decorrer, caso esse princípio fosse contrariado.

Townsend antecipou parte importante dos argumentos de Thomas Malthus em mais de uma década. Entre as publicações de Uma dissertação sobre a Lei dos Pobres e Ensaio sobre o princípio da população (ou apenas Ensaio sobre a população), isto é, entre 1786 e 1798, a eclosão da Revolução Francesa deu fôlego ao otimismo em relação à questão social e ao gênero humano em si, cuja melhor expressão na Inglaterra se deu com Thomas Paine e seu Direitos do homem de 1791. O ímpeto de transformação levou autores a exaltarem a concepção de direitos inalienáveis a todos os cidadãos, alegando que a razão e a democracia poderiam dar 
início a uma nova era de progresso contínuo, capaz de elevar mesmo os mais pobres em intelecto, moralidade e espírito. Defendeu-se que a pobreza não precisava mais ser encarada como uma sina inexorável da humanidade, podendo ser superada em definitivo com o fim da tirania e do parasitismo do clero e da aristocracia, consideradas as causas da desigualdade (Jones, 2004). O Ensaio sobre a população veio para interromper bruscamente esse êxtase. Malthus (1998) sustentou que a existência de leis de ferro da natureza, que em última instância manifestavam a vontade divina, esvaziava qualquer expectativa quanto ao conceito de perfectibilidade humana, o ideal de que os indivíduos e a sociedade possuíam um potencial ilimitado de aprimoramento. A forma mais explícita pela qual essas leis se manifestavam era pelo princípio da dinâmica populacional, uma versão mais elaborada do argumento naturalista que havia sido esboçado por Townsend. Através da constatação de que a capacidade humana de reprodução superava em ritmo a capacidade da agricultura de gerar alimento, e que o aumento da riqueza material numa sociedade introduzia a tendência de expansão demográfica, ao incentivar que os casais contraíssem matrimônio mais cedo, incorria-se no pressuposto de que o progresso econômico sempre esbarraria cedo ou tarde nessa contradição, terminando em crises de subsistência.

Por mais que lamente a desigualdade gritante visível na Inglaterra, Malthus (1998, p. 79-83) entende que a divisão entre proprietários e despossuídos obrigados a vender sua força de trabalho é uma necessidade estrutural, reabilitando a ameaça permanente da fome como um mal indispensável e principal forma de incentivo ao trabalho. Cabia aos favorecidos pela grande loteria da vida, que haviam nascido na posição de abastados, zelar pela propriedade privada e utilizá-la da forma mais racional e eficiente possível, enquanto os menos afortunados deveriam abraçar a labuta, a moderação e a temperança para se colocarem a serviço de seus empregadores. Como já estava estabelecido na tradição pessimista, considerava-se que as paixões e a tentação pela devassidão eram inerentes ao espírito humano. Se mesmo os ricos e instruídos podiam ser seduzidos por elas, não era de esperar que os pobres e incultos fossem capazes de resistir, se não estivessem sob a constante pressão exercida pela subsistência. Os privilegiados aprendiam a preferir prazeres refinados em relação à diversão ordinária porque dispunham 
de meios para experimentá-los, opção que estava evidentemente vedada para as classes populares. Não se afastariam da preguiça e do alcoolismo por vislumbrarem perspectivas e diversões mais enobrecedoras, que não eram próprios de sua condição, mas, sim, pelo medo da miséria extrema.

Novamente, coloca-se que a Lei dos Pobres subvertia essa ordem. Qualquer dispêndio público concedido aos que não trabalhavam dava-se sempre em detrimento dos laboriosos. Uma lei que concedia às autoridades paroquianas poderes para extorquirem os contribuintes honestos poderia ser apenas de cunho tirânico. Por entender que esse sistema, de tão entranhado na sociedade inglesa, não poderia ser abolido de forma repentina sem resultados catastróficos, Malthus (1998, p. 29-30) propõe que sua extinção se dê de forma gradativa. $\mathrm{O}$ primeiro passo seria, em concordância com Smith, acabar com toda a legislação que de alguma forma dificultava a livre circulação dos pobres, na expectativa de que assim estes se dirigissem mais facilmente para onde havia demanda por trabalho. Em seguida, extinguir igualmente qualquer instituição que tornasse o trabalho urbano mais caro do que o rural, como o sistema de aprendizagem ou as corporações de ofício, tirando o incentivo para se abandonar o trabalho no campo, necessário para se alimentar a população. Finalmente, orienta que sejam edificadas workhouses ${ }^{2}$ municipais mantidas por contribuições voluntárias, projetadas como espaços pouco confortáveis e de trabalho pesado. A internação nesses centros era a única modalidade de socorro que deveria ser oferecida, assegurando que apenas os verdadeiramente desesperados recorressem à ajuda pública. Em prol de se promover o espírito de independência e dignidade entre a gente comum, condição imprescindível para a felicidade da sociedade, era preciso que o ato de se solicitar qualquer espécie de abono público fosse revestido de desonra, e o solicitante estigmatizado.

Durante as duas primeiras décadas do século XIX, a economia política britânica foi dominada pelo debate entre Malhtus e David Ricardo, no qual a questão principal era a renda da terra, reproduzindo a tensão política entre um capitalismo agrário instituído fazia mais de um século e o capitalismo industrial ascendente. Apesar de discordâncias impor-

2 Literalmente, "casas de trabalho", instituições de trabalho e vigilância que funcionavam como abrigo para desamparados. Nelas, esperava-se que os internos sadios exercessem trabalho como forma de compensar o gasto que representavam para os contribuintes. 
tantes, Ricardo abraçou a teoria populacional malthusiana, reproduzindo o pessimismo em relação aos salários da classe trabalhadora, que tendiam ao nível da subsistência pelo fato de que qualquer enriquecimento material favorecia o aumento da população que, com o tempo, pressionava para baixo o preço da mão de obra. Ricardo (1821, p. 68-69) era avesso às legislações que intervinham sobre os contratos da esfera privada, inclusive as relações de trabalho, sendo o salário algo cujo preço deveria ser regulado pelo livre mercado, assim como qualquer outra mercadoria. A Lei dos Pobres, ao invés de enriquecer os pobres, na prática estava apenas empobrecendo os ricos, dragando recursos dos contribuintes em uma escalada sem fim de aumento de despesas. As guerras contra a França revolucionária no final do século XVIII, seguidas pelas campanhas contra Napoleão que se arrastaram até 1815, período no qual os preços dos produtos agrícolas subiram ainda mais, castigaram principalmente os mais pobres, fazendo com que as solicitações de socorro paroquial atingissem um pico. Nos primeiros anos do século XIX, os gastos anuais já estavam na faixa dos 4 milhões de libras, atingindo uma máxima durante os anos imediatamente posteriores ao fim da guerra, quando esse número atingiu um pico de 8 milhões em 1818. Na década de 1820 , com a sofrida recuperação econômica, os valores oscilaram entre algo em torno de 6 e 7 milhões de libras (Boyer, 2002), quantia considerada intoleravelmente alta para a classe média aburguesada.

Dentro do conjunto de discursos que poderiam ser enquadrados naquilo que poderíamos classificar como derivados do liberalismo, isto é, posicionamentos assentados na exaltação de uma economia de livre mercado como melhor alternativa para o funcionamento da sociedade, pode-se observar, a partir das reflexões geridas dentro da economia política, uma linha de influência crescente associada à hostilidade perante a Lei dos Pobres. Esta articulava um repúdio por intervenções estatais no mercado de trabalho, com um severo pessimismo diante da natureza humana, que, embora fosse apresentado como uma característica universal, discriminava ricos e pobres como categorias de inclinações diferentes entre si. Isso foi construído em cima de uma combinação de determinismo naturalista e filosofia moral, mas com o cuidado de revestir as opiniões arbitrárias com um viés cientificista neutro. O representante máximo dessa conjunção foi Malthus, cuja teoria repercutiu 
de forma onipresente durante a primeira metade do século XIX, em todos os debates sociais da Inglaterra. Forjada em interação com a economia política, a filosofia utilitarista, apresentada em 1798, em Uma introdução aos princípios da moral e da legislação, do jurista Jeremy Bentham, oferecia um embasamento teórico para aqueles que se propunham a tornar mais "científico" seus projetos sociais. A ferramenta para tal era o "utilitarismo", filosofia que obteve seu nome a partir do "princípio da utilidade" ou "princípio utilitário", que Bentham (1823, p. 50-54) cunhou com o propósito de estabelecer um padrão para estimar a extensão negativa ou positiva dos efeitos de uma decisão individual ou governamental. A partir de uma série de critérios específicos (sendo os mais importantes a intensidade, a duração, a certeza e a propinquidade), poderia se estipular a positividade ou negatividade de uma ação pelas suas consequências, por meio de uma espécie de cálculo em que esses critérios ocupariam o lugar das variáveis. Esse método convencia Bentham de que seu utilitarismo era uma fórmula confiável para inferir se um fenômeno social gerava mais dor ou prazer, isto é, se ele era bom ou ruim para o todo.

A Lei dos Pobres, ao aliviar sofrimentos pontuais em detrimento de um conjunto maior, era claramente um exemplo de medida negativa. Bentham também havia contribuído com ideias influentes acerca da vigilância sobre pobres e transgressores, pregando que a assistência pública deveria seguir os moldes do sistema carcerário ao se uniformizar e centralizar, instituindo um controle pelo alto que garantisse um funcionamento homogêneo em todo o país. Recomendou a construção de novas workhouses projetadas com um viés mais punitivo do que havia até então, assim como um cadastro nacional para os pobres e o envio de crianças carentes para as fábricas como aprendizes a partir dos 4 anos. $\mathrm{O}$ que podia ser entendido como um cerceamento das liberdades individuais e uma retirada da autonomia decisória das paróquias era justificado pelo princípio utilitário, pois traria ordem para a sociedade. Sacramentava dessa forma o retrato dos pobres como seres adoentados de moral e intelecto, que só poderiam ser salvos de suas deficiências pelo trabalho (Himmelfarb, 1988, p. 97-105). 


\section{A reforma de 1834: a instituição da Nova Lei dos Pobres}

A junção de ideias da economia política com o utilitarismo forneceu o argumento para aqueles que vieram a se organizar na campanha difamatória contra a Lei dos Pobres, responsáveis por encabeçar a reforma de 1834. Com a chegada da década de 1830, o debate político-econômico foi acrescido pela "questão fabril", isto é, a análise sobre os impactos que a indústria moderna vinha exercendo sobre o corpo social, especialmente no que diz respeito à pobreza em suas múltiplas facetas. Os três grandes economistas clássicos que se destacaram antes de 1830, Smith, Malthus e Ricardo, dedicaram pouca atenção ao tema. Smith escrevera em um momento inicial da Revolução Industrial, em que os efeitos mais nefastos desta ainda eram pouco observados. Nas primeiras décadas do século XIX, Malthus e Ricardo já testemunhavam mais claramente consequências negativas da industrialização e os atritos que estas geravam, ainda que fosse possível argumentar que o problema estava mais atrelado às imposições das guerras contra a França até 1815 e a crise que se seguiu. O modo como Malhtus (1998, p. 113-114) defendia a agricultura era imbuído de uma repulsa pela nova economia urbana industrializada, como deixa sugerido em comentários nos quais associa as grandes cidades em expansão com a imoralidade e a miséria humana. Por sua vez, Ricardo (1821, cap. 31) incluiu na terceira edição de seu Princípios em 1821 um capítulo sobre o efeito da maquinaria moderna, no qual reconhece que a revolta dos operários contra o desemprego tecnológico possuía embasamento, indicando que o conflito de interesses entre patrões e empregados não poderia ser uma questão pouco abordada pelos economistas por mais muito tempo. Mas ambos preocuparam-se majoritariamente com a disputa entre o interesse fundiário e industrialista, isto é, nobreza e burguesia urbana. A tensão vertical entre a classe trabalhadora e os que se apropriavam de seu trabalho não era alvo de atenção principal entre os expoentes mais renomados da economia política.

O quadro era outro nas décadas de 1830 e 1840, período marcado por um agravamento desses enfrentamentos no plano político, ao mesmo tempo em que indicadores biológicos de padrão de vida se degradavam em relação ao momento anterior ${ }^{3}$, deixando evidente que a pobreza e

3 Para um balanço atualizado sobre a questão dos padrões de vida durante a Revolução 
desigualdade observadas eram fenômenos complexos demais para não dedicar a elas olhares mais elaborados. Observa-se entre diversas facções um senso de urgência na busca por apresentar respostas para o que se entende como uma situação insustentável e perigosa. Entre os segmentos da classe média mais afinados com o livre mercado, como os ligados ao comércio urbano e às manufaturas, encontrar essas soluções era entendido como forma de assegurar a manutenção do projeto de sociedade que tinha o sistema fabril e o laissez-faire como pilares estruturais. Mas isso se mostraria uma tarefa importante e impreterível demais para se deixar ao cargo de um punhado de intelectuais destacados, ou para se restringir a debates teóricos dissociados da prática direta da gestão da coisa pública. Nesse sentido, é perceptível, a partir dos anos 1830, a atuação proeminente de figuras identificadas com um liberalismo mais incisivo, dedicado a apresentar princípios do livre mercado como alternativa necessária para a resolução dos distúrbios sociais constatados.

É dificil precisar os contornos dessa iniciativa de origem burguesa, uma vez que ela não assumiu em seu conjunto uma identidade expressa por meio de uma instituição ou um nome que lhe conferissem clara unidade. Embora ela tenha produzido, entre 1838 e 1846, uma associação com programa e aspecto bem definidos, a Liga Antilei dos Cereais ${ }^{4}$, essa campanha não expressa a totalidade das pretensões com as quais a burguesia organizou-se nesses anos, mas, sim, uma fração, ainda que certamente de grande importância para sua ideologia e suas aspirações. Politicamente, os representantes desse esforço amplo estavam alinhados ao Partido Whig, crescentemente identificado com as burguesias urbanas. Mas não seria congruente entender whigs ou tories ${ }^{5}$, as duas grandes forças dentro da

Industrial, conferir Voth (2006). Observa-se que indicadores biológicos, como a expectativa de vida ao nascer e a altura constatada entre recrutas, declinam durante as duas décadas destacadas em relação à década de 1820 .

4 Fundada em 1838, essa associação, concebida por industrialistas proeminentes, dedicou-se a pressionar politicamente pelo fim das Leis dos Cereais, como era conhecida a legislação protecionista instituída em 1815, com a finalidade de impedir que os grãos ingleses se desvalorizassem demasiadamente no mercado interno, após o fim do esforço de guerra. Ao taxar pesadamente a importação de cereais, essas leis mantiveram o preço dos produtos agrícolas em um patamar elevado, beneficiando fazendeiros. Empregadores de setores não agrícolas revoltavam-se pelo encarecimento do custo de vida que isso implicava, pressionando os salários para cima.

5 Originalmente, os whigs correspondiam à congregação de poderes aristocráticos, que, com apoio da alta burguesia e dos grupos mais populares, derrotara a Monarquia e 
Câmara dos Comuns ${ }^{6}$, como blocos unificados em torno de programas claramente estabelecidos. A organização de ambos, dentro do padrão daquilo que pode ser entendido como um partido político em sentido contemporâneo, era algo novo. Desde que haviam emergido no século XVII, as duas facções mais se assemelhavam a alianças entre grupos e famílias importantes que se fazem influentes no Parlamento, desprovidas da coesão fornecida por projetos de governo verdadeiramente partidários. É no final do século XVIII, conforme novas questões políticas começam a instigar politicamente a população inglesa, que o jogo de interesses assume contornos mais próximos às alianças partidárias, com whigs angariando a força dos novos industrialistas e classes médias urbanas em geral, enquanto seus rivais tories reuniam a maior parte dos proprietários rurais e oficiais militares. Por mais que tendessem a reunir, respectivamente, homens ligados à riqueza urbana e ao capital fundiário, esse simples dualismo não era suficiente para enquadrar o conflito e articulação de interesses em um cenário econômico cada vez mais complexo, gerando grau elevado de discordância interna nos dois grandes partidos.

Há, contudo, abundância de publicações a partir de 1830, reivindicando mudanças políticas consistentes em prol do livre mercado. Esses escritos se distinguem de materiais redigidos em períodos anteriores pelo modo como expressam sintonia com a série de reformas instituídas pelo Parlamento entre 1832 e 1846. Seus autores são profissionais liberais, alguns acadêmicos, jornalistas, empregadores, técnicos especializados no setor produtivo e outras ocupações típicas da classe

impusera a supremacia do Parlamento nos conflitos do século XVII. Tinha como princípios importantes a tolerância religiosa e a Monarquia constitucional. O Partido Tory, por sua vez, fora sempre associado ao conservadorismo, surgindo para representar a nobreza defensora da Coroa, ligada ao anglicanismo. Essa esquematização é apenas um esboço da composição geral desses setores no momento em que os partidos foram instituídos, que sofrerá mudanças até o século XIX. Em 1834, o Partido Tory muda seu nome para Partido Conservador, mas continua sendo comumente referenciado pelo termo anterior. Já o Partido Whig se dissolve em 1859, em seu lugar surgindo o Partido Liberal.

6 A Câmara dos Comuns congregava os parlamentares eleitos nas zonas eleitorais. A outra casa do Parlamento era a Câmara dos Lordes, reservada ao alto clero e à nobreza, em que os membros obtinham espaço por meio de direitos de título, não sendo, portanto, representantes eleitos. Com a Guerra Civil e a Revolução Gloriosa no século XVII, a Câmara dos Comuns cresceu muito em importância e se tornou o espaço com maior poder decisório dentro da vida política inglesa. 
média urbana. O formato publicado varia do livro ao folhetim, do artigo de jornal à monografia científica. Tal amplitude pode sugerir que a tentativa de enquadrá-los em um conjunto é excessivamente arbitrária. Mas há uma mudança de postura no discurso de alas da burguesia, que, atuando em conjunto com o reformismo político, expressam um desejo de afirmação do liberalismo industrializante como norteador para a organização da sociedade. Perry Anderson (1964, p. 31-32), nos textos que vieram a compor seu famoso debate com Thompson, ao esboçar seu modelo para explicar a emergência da ordem burguesa na Inglaterra em simbiose estreita com o mundo aristocrático, apontou exatamente para esse recorte temporal como uma fase excepcional pelo modo como iniciativas burguesas colidem com interesses da nobreza fundiária. Esse "momento heroico" mostrou-se uma ruptura momentânea com uma atitude até então caracterizada pela conciliação em posição submissa, em que o mundo burguês reconhece a supremacia política e cultural do halo aristocrático, com a condição de que esse pacto leve em consideração as expectativas econômicas dessa classe média enriquecida. $\mathrm{O}$ primeiro marco deu-se com a reforma parlamentar instituída em 1832, resultado de intensa pressão política que articulou a classe média urbana e os trabalhadores, exigindo maior representatividade. A reforma redesenhou as zonas eleitorais, retirando assentos parlamentares de regiões agrícolas e contemplando com representantes eleitos regiões industriais em crescimento. Manteve-se, contudo, critérios censitários com base na propriedade, para se obter o direito ao voto e para se candidatar à Câmara dos Comuns, para a frustração das classes populares que se viram privadas do fruto dessa conquista. Com a mudança abrindo espaço para uma maioria parlamentar whig inédita no século XIX, uma burguesia que até então dependia de uma baixa nobreza mais afinada ao comércio, para representar seus interesses no Parlamento, enfim adentrava esse espaço restrito.

As grandes reformas introduzidas com essa nova conjuntura foram a abolição da escravidão no Império, em 1833, o Ato de Emenda da Lei dos Pobres, em 1834, e a abolição das Leis dos Cereais, em 1846. Nenhuma dessas iniciativas, tal qual havia sido com a própria reforma eleitoral, deu-se por obra de uma burguesia isolada. Se, para acessar o Parlamento, articularam-se forças com trabalhadores e radicais, a dinâmica dentro da Câmara dos Comuns exigia mobilizar apoio de ao menos parte dos 
setores ligados às classes fundiárias. Isso não invalida, entretanto, o caráter transformador dessas reformas. É evidente que não houve um rompimento aberto com o pacto de dominação entre as elites, firmado entre a nobreza de linhagem, a gentr ${ }^{7}$, e a alta burguesia, mas certamente esta última entendeu que chegara seu momento para reivindicar uma renegociação dos termos desse acordo secular. Nenhuma das partes envolvidas na contenda tinha interesse em mobilizar a força popular após 1832, entendida como um fator de risco inaceitável em um período conturbado. A empreitada reformista e o esforço de conquista de consenso que esta exigia para ser bem-sucedida eram uma operação delicada, que exigia um mapeamento das forças alocadas nesse xadrez político em que as articulações poderiam ser inusitadas (é bom lembrar que o fim das Leis dos Cereais só foi possível com o apoio de um primeiro- ministro torie $^{8}$ ). Isso se somava ao fato de que a identidade burguesa como uma esfera política e cultural autônoma e com programas de classe próprios era uma construção incompleta, que ia se estruturando à medida que o setor industrialista tentava se afirmar como potência dirigente extraeconômica.É o que torna tão difícil delinear os contornos desse movimento de forma que se reconheça sua importância e grande pretensão, mas sem cair na concepção anacrônica de um ataque fulminante orquestrado por uma burguesia já consolidada, coesa e organizada em torno de projetos de poder perfeitamente traçados. Ainda em 1844, o jornalista irlandês William Taylor explicava da seguinte maneira o fato de que, em sua visão, os industrialistas eram incapazes de desmentir a imagem negativa que a opinião pública mantinha sobre a realidade fabril:

A resposta para isso já foi dada: os empregadores nunca se organizaram como um corpo, nunca agiram juntos e nunca olharam para si como formando uma classe ou ordem. Por mais irritados que se sintam individualmente,

$7 \quad$ Espécie de nobreza togada de proprietários rurais, ostentando títulos inferiores fora do pariato. Mais numerosa do que a alta aristocracia, obteve enorme influência política e riqueza após as revoluções do século XVII, ainda que seu prestígio, pela tradição, fosse considerado inferior ao dos nobres de linhagem.

8 Robert Peel, primeiro-ministro entre 1841 e 1846, era filho de um industrialista riquíssimo e expressara simpatia pelo livre mercado desde sua juventude. $\mathrm{O}$ fato de ter manobrado em favor da revogação das Leis dos Cereais fez com que perdesse o apoio dentro do seu partido, levando-o a resignar-se. Falecido em 1850, seus seguidores mais próximos estavam entre os fundadores do Partido Liberal em 1859. 
eles não têm meios de protestar coletivamente, eles não têm influência na legislatura nem meios disponíveis de fazer um apelo aos seus compatriotas. (Taylor, 1844, p. 50)

Taylor exagera ao alegar que os empregadores da indústria (especificamente se referindo aos empregadores da grande indústria têxtil) estavam desprovidos de influência legislativa ${ }^{9}$. Mas sua opinião sugere que o processo de formação de uma classe empresarial de grandes industrialistas não estava amadurecido. Essa constatação é necessária para se analisar o processo de transição para a dominação do capital industrial, evitando simplificações anacrônicas. Entretanto, isso não equivale a reduzir a pó, na busca por modelos explicativos, a capacidade dessa nova burguesia, diretamente ligada ao setor mais moderno e dinâmico da economia inglesa, de exercer socialmente sua influência sobre estratos mais amplos. Nem se pode negar a existência de agentes importantes que, ainda que não pertençam estritamente a esse pequeno círculo de grandes patrões, atuam de forma a ecoar as aspirações destes tanto no espaço político institucionalizado, quanto na sociedade civil como um todo.Thompson (2001, p. 252-263) alertou para o risco de que etapismos rigorosamente estabelecidos na percepção das dinâmicas classistas podem conduzir a percepções enganosas, como acreditar que a atuação de classe, em suas alianças e seus antagonismos, significará sempre o produto acabado de um longo processo de conscientização que a precede. $\mathrm{Na}$ verdade, é possível (se não na totalidade, ao menos em um número significativo de exemplos históricos) constatar a execução de estratégias classistas ao longo da extensa caminhada, marcada por oscilações e contradições, que a classe atravessa em direção ao estágio no qual enfim se encontra articulada para instituir os órgãos de representação identitária que caracterizam sua maturidade. Dessa forma, há como identificar nessas duas décadas decisivas para a Revolução Industrial a atuação destacada de uma intelectualidade heterogênea em uma diversidade de campos, guardando como traço comum a adoção de um programa

9 O histórico da legislação trabalhista relativa ao setor, caracterizado até 1847 por uma sucessão de atos fabris que estabeleciam critérios etários para o emprego de crianças e adolescentes estipulados após intensa negociação com os próprios patrões, é apenas um indício da força política desse patronato e sua capacidade de influenciar as leis. Conferir Kirby (2003). 
radicalizado em sua proposta de assentar as bases econômicas da sociedade britânica sobre o livre mercado e a indústria.

Como comentado, essa intelectualidade era composta por profissionais de atividades variadas comuns à classe média. $\mathrm{O}$ fato de que provinham de campos diversificados denota que a industrialização, na condição de projeto político, ainda que não expresso através de um partido ou entidade hegemônica plenamente desenvolvida, já era interpretada por parte significativa da burguesia como uma estratégia totalizante, isto é, um modelo orientador de sociedade e não meramente uma forma produtiva estritamente econômica. Na ausência de uma unidade classista desse setor e seus intelectuais associados em torno de um programa debatido internamente e minuciosamente estabelecido, como se esperaria de um bloco de classe em estágio avançado de organização e conscientização, as pautas desse projeto são levantadas em frentes distintas nem sempre bem articuladas entre si, mas que resguardam alguma coesão programática assegurada pelo senso de urgência imposto pela delicada situação sociopolítica. O desmanche da ordem que vigorou através do século XVIII, no qual a hegemonia cultural da gentry rural em relação à plebe campestre assegurou relativa estabilidade com base em relações patriarcais, encaminhou-se de forma irreversível a partir de 1790, com a industrialização corroendo esses laços tradicionais e a paranoia permanente entre as elites econômicas com qualquer sinal de radicalismo ou auto-organização trabalhista. Havia a sensação de um perigoso vazio de hegemonia que, se por um lado oferecia à burguesia industrialista a oportunidade de estabelecer-se mais firmemente entre as classes dirigentes, em contrapartida, também deixava espaços para a classe trabalhadora urbana aspirar a caminhos independentes ou aproximar-se do radicalismo jacobino de classe média. Definir paradigmas econômicos que estabelecessem livre mercado e indústria como eixos do progresso e do bem-estar envolveria, para além de reformas legislativas, grande esforço de convencimento social. O programa industrializante é também estratégia política de hegemonia social, restabelecimento de uma ordem capaz de cooptar ao menos a parte mais influente e articulada da classe trabalhadora ${ }^{10}$. O descrédito da autonomia

10 Foster (2005,p. 197-203) aponta para a estratificação entre trabalhadores qualificados e não qualificados como um caminho explorado pelo patronato para rachar o mo- 
dos trabalhadores como alternativa válida é perceptível em todo discurso que exprime esse grande projeto, sendo um dos elementos que confere alguma unidade à sua formação um tanto difusa.

Identificado em numerosas publicações de diferentes formatos, um modelo em especial parece traduzir melhor o modus operandi dessa intelectualidade apegada ao industrialismo: o inquérito social, material que se multiplica a partir de 1830 , partindo tanto de iniciativas individuais, quanto do serviço de comissões públicas nomeadas pelo Parlamento. Conhecidos como blue books, em referência à encadernação azul que geralmente recebiam em suas edições, configuram notoriamente fontes primárias valiosíssimas sobre a questão social do período, consistindo de relatos e investigações minuciosas sobre questões que dominavam o interesse público, como o estado sanitário dos centros urbanos, o trabalho infantil-juvenil, a decadência dos ofícios arruinados pela competição com as fábricas (caso da tecelagem manual), além, é claro, do interesse principal deste artigo, o funcionamento da Lei dos Pobres. Tais publicações reivindicam metodologia e caráter científico em suas abordagens, tentativa de conferir ares de neutralidade de parecer cirúrgico a escritos que eram, por via de regra, impregnados de ideologia política. Se era um consenso que a situação social era calamitosa, a disputa por narrativas e interpretações era um campo diversificado. Inquéritos foram publicados pelas mãos de conservadores tories e radicais de esquerda, passando, é claro, pelos advogados do livre mercado, majoritariamente alinhados direta ou indiretamente à ala whig. Em determinados tópicos, esse enfrentamento consistiu em um duelo equilibrado, como no caso da exploração do trabalho de menores em fábricas, questão de forte apelo moral mesmo entre a classe média e que o conservadorismo fundiário soube explorar com maestria para atiçar a indignação popular

vimento trabalhista, explorando o receio dos primeiros de perderem sua posição relativamente privilegiada. Esse esforço parece ter frutificado na segunda metade da década de 1840, quando é comum ver trabalhadores se afastarem do radicalismo e aderirem politicamente a liberais ou conservadores. Berg (1982,p. 145-161) destacou a participação de centenas de institutos mecânicos fundados na Grã-Bretanha, entre as décadas de 1820 e 1840, nesse movimento de cooptação. Nessas instituições, financiadas por capital industrial, os operários eram incentivados a participarem de encontros em que se discutiam ciências naturais aplicadas e economia política, enfatizando a importância de se aderir à organização fabril e dominar os segredos da engenharia de produção como forma de ascender na hierarquia industrial. 
contra o sistema fabril, obrigando o setor industrialista a mobilizar-se para apresentar seus próprios relatórios desacreditando as denúncias mais comprometedoras $^{11}$.

No que diz respeito à Lei dos Pobres, a contenda foi vencida mais rapidamente. Tido como uma prioridade entre as reformas a serem instauradas após o estabelecimento da maioria whig em 1832, o sistema paroquial de amparo aos pobres foi sistematicamente difamado em inquéritos públicos e particulares sem que defensores pertencentes às esferas mais influentes se apresentassem publicamente para defendê-lo à mesma altura. Por mais que os fazendeiros empregadores nas zonas rurais do Sul e do Leste, onde a Lei dos Pobres era mais abrangente, se beneficiassem desses recursos na condição de uma espécie de subsídio indireto aos salários, episódios recentes de violentos motins rurais entre 1830 e 1831 (os chamados Swing Riots) haviam despertado desconforto entre os proprietários. A nobreza arrendadora das terras utilizadas por esses fazendeiros veio a apoiar o Ato de Emenda em 1834, receosa diante da perspectiva de uma classe trabalhadora mobilizada para reivindicar direitos, além de incomodar-se com a alta dos impostos paroquiais, dado que, por sua riqueza ser oriunda sobretudo da renda, e não diretamente da exploração do trabalho, não se beneficiava com o efeito de subsídio salarial da Lei dos Pobres, descrito mais adiante. A aristocracia e a gentry também passaram a olhar com desconfiança para seus arrendatários, suspeitos de terem mantido postura passiva durante as revoltas recentes, ou mesmo de terem atiçado a ira dos manifestantes para fins próprios, alegando que eram impedidos de pagarem salários dignos por conta das altas taxas com as quais tinham de arcar em troca da posse de suas fazendas (Boyer, 2006, p. 198, 204). Entre categorias mais populares, privadas do espaço político oficial, a oposição à reforma se expressou na forma de tumultos dispersos facilmente contidos. Talvez pelo fato de que a organização dos trabalhadores fosse maior nas cidades, onde os abonos extramuros não eram uma questão tão delicada quanto

11 Engels (2010,p. 155) fez um relato breve e consistente desse embate político em seu famoso inquérito sobre a situação dos trabalhadores ingleses, publicado na Alemanha, em 1845. É irônico constatar que, embora o trabalho de Engels tenha entrado para a história como o mais célebre entre os inquéritos sociais da Revolução Industrial inglesa, ele teve pouca repercussão entre os ingleses do século XIX, recebendo a primeira edição em inglês apenas em 1887, nos Estados Unidos. Só em 1891 os ingleses foram contemplados com uma edição própria. 
no campo, não se viu tanta mobilização por parte desses setores. Para além dos fazendeiros, interessados na manutenção dos abonos extramuros, as vozes opositoras mais reverberantes ficaram restritas a um punhado de tories mais afinados com a população carente e os poucos parlamentares radicais. A obstinação contra a reforma, contudo, aumentou após esta já estar configurada: a partir de 1834, periódicos radicais irão denunciar incessantemente o novo sistema de workhouses, que se tornará rapidamente uma instituição odiada entre a população trabalhadora.

Assim sendo, o inquérito publicado em 1832, intitulado A condição moral e física das classes trabalhadoras empregadas na manufatura de algodão em Manchester, redigido pelo médico James Phillips Kay-Shuttleworth, consiste em um dos primeiros exemplos desses manifestos expressando o ímpeto reformista. Abordando a condição dos operários de um dos principais polos industriais do país, o autor retoma antigos argumentos contrários a Lei dos Pobres, para apontá-la como causa do estado miserável em que se encontrava aquela gente. Colocando o sistema fabril e o laissez-faire como sinônimos de civilização e riqueza material, a explicação para a miséria humana que se via concentrada nos centros manufatureiros só poderia se dar por causas externas, que interferiam sobre o bom funcionamento dessa dupla:

Acreditando que a tendência natural do comércio irrestrito é a de desenvolver as energias da sociedade, de aumentar os confortos e luxos da vida e de elevar a condição física de cada membro do corpo social, nós temos exposto, com uma mão acurada, ainda que amigável, a condição das ordens mais baixas conectadas com as manufaturas desta cidade, porque concebemos que os males afetando-as resultam de causas externas e acidentais. Um sistema que promove o avanço da civilização e a difunde sobre o mundo - que promete manter a paz entre as nações, pelo estabelecimento de uma lei internacional permanente, fundada nos benefícios da associação comercial - não pode ser inconsistente com a felicidade da grande massa das pessoas. (Kay-Shuttleworth, 1832, p. 47)

Entre as arbitrariedades que atravancavam essa máquina de prosperidade, que incluiriam o protecionismo praticado pelos governos europeus e a atuação sindical dos trabalhadores, encontrava-se a Lei dos Pobres:

A Lei dos Pobres providencia, receamos, muito frequentemente um apelo pela imprevidência e ociosidade. Quando imprudente com o futuro, 
a inteligência do homem é confinada pelos limites estreitos do presente. Com esse passo ele se coloca abaixo dos animais, cujos instintos ensinam eles a fazer estoques para as estações de necessidade. A estrutura artificial da sociedade, ao prover segurança contra males existentes, muito frequentemente negligenciou a influência moral de seus arranjos sobre a comunidade. A humanidade alegra-se na consciência de que os pobres podem obter as vantagens do tratamento cuidadoso na doença e socorro na necessidade, de que haja asilos para a enfermidade, velhice e decrepitude, mas a extensão ilimitada dos benefícios, idealizada por uma inteligência ajuizada para o alívio dos males que nenhuma presciência humana poderia evitar, tem uma tendência direta a encorajar, entre os pobres, apatia, concernindo presentes exigências e a negligência quanto a uma provisão para as contingências do futuro. Os efeitos disso irão ser favoráveis a cada outra causa desmoralizante, e irão daí em diante operar mais poderosamente entre os que são mais degradados. (Kay-Shuttleworth, 1832, p. 28-29)

No fragmento acima, Kay-Shuttleworth denuncia o que acreditava ser um senso equivocado de humanidade entre os ingleses, que os levava a conceder beneficios incondicionais, visando aliviar os necessitados, mas sem perceber que com isso estavam minando o senso de esforço próprio e a previdência da classe trabalhadora. A ênfase dada no caráter irrestrito dessa ajuda procura fortalecer a ideia de que viver à custa da paróquia havia se convertido em um modo de vida muito mais convidativo do que o trabalho honesto. No ano seguinte, Peter Gaskell publicava, a pedido do Parlamento, outro inquérito sobre a classe operária, tendo agora um escopo maior ao tomar como parâmetro o quadro nacional. O tom assumido no relatório é menos alarmista do que o de Kay-Shuttleworth, mas as conclusões seguem as mesmas linhas. Considerando que sua preocupação primária em relação aos trabalhadores era restabelecer uma estrutura familiar idealizada, em que o pai era o provedor sóbrio e responsável do recurso material e a mãe a zeladora do lar e da criação dos filhos, Gaskell assim descreveu o efeito da Lei dos Pobres sobre essas uniões:

A Lei dos Pobres e as leis dos bastardos ${ }^{12}$ atuaram inquestionavelmente,

12 Gaskell se refere com bastardy laws às leis que possibilitavam que mães solteiras acionassem a paróquia para obrigar os pais de seus filhos a pagarem pensão, caso estes recusassem o casamento. 
e ainda estão atuando, como prêmio para imoralidade e ociosidade. Isso é produzido, por um lado, ao tornar o homem pobre imprevidente, ao prover um fundo sobre o qual ele pode se abster do trabalho; e, por outro, destruindo a castidade das moças, e assim arruinando todas aquelas associações enobrecedoras que deveriam marcar o intercurso entre os sexos, e pervertendo a mais sagrada entre todas as relações humanas - a do casamento. Que esses males sejam atribuídos tanto a uma falta de administração apropriada quanto aos efeitos inerentes dessas leis, não pode ser negado; mas leis que abrem uma porta tão ampla e tentadora para libertinagem e imprevidência devem certamente estar carecendo de alguns dos atributos apropriados dos decretos legislativos. (Gaskell, 1833, p. 216-217)

Observa-se, nos trabalhos de Kay-Shuttleworth e de Gaskell, a ambição de levar a economia política a uma abordagem mais prática das questões sociais, afinando-a com um discurso que combina austeridade da despesa pública e valorização de uma ética do trabalho. Exigia-se um corte abrupto nas políticas assistenciais, estigmatizadas da mesma forma que seus beneficiários. Uma reforma radical já se desenhava em fevereiro de 1832, quando o Parlamento nomeia uma comissão pública para inquirir sobre o funcionamento da Lei dos Pobres em toda a Inglaterra e no País de Gales, bem como levantar propostas para interromper a escalada de gastos. Os 9 comissários principais e 16 comissários assistentes incumbidos com a tarefa tiveram pouco tempo e poucos recursos para realizar sua investigação, e admitiu-se abertamente que alguns condados sequer foram visitados, enquanto a metrópole londrina foi simplesmente ignorada e sequer é mencionada no material final. Mas isso não vinha ao caso. As conclusões já estavam tomadas desde o começo. O relatório apresentado ao Parlamento, originalmente na forma de 13 volumes, que começam a ser publicados em fevereiro de 1833 e terminam no ano seguinte, foi redigido basicamente por apenas 2 comissários, que haviam assumido para si a chefia da comissão. Eram Nassau Senior, advogado de formação que se converteu em professor de economia política, e Edwin Chadwick, outro advogado com notável ambição de subir na carreira pública e impressionante obstinação reformista.

As páginas do relatório concentraram seu fogo contra o socorro extramuros, que correspondia a toda forma de ajuda oferecida aos pobres fora dos limites físicos de instituições projetadas com esse fim. Indignava a comissão a existência do que interpretavam como uma cultura 
generalizada de concessão de esmolas.Além de repetir afirmações antigas, de que essa prática pervertia a ordem natural da economia e minava o espírito de trabalho e moralidade da gente comum, acusa-se a Lei dos Pobres de funcionar como um subsídio indireto para os salários nas fazendas. O mecanismo institucional que permitia isso era o Sistema Speenhamland (ou Lei Speenhamland), criado em 1795 como resposta para a miséria no campo, durante um ano de colheitas ruins. Com ele, tabelas eram fixadas nas paróquias, para parear o valor dos abonos ao preço do pão, com o intuito de evitar que esses pagamentos ficassem muito abaixo do custo de subsistência. De acordo com os redatores do inquérito, os empregadores rurais aproveitavam-se disso para pagar baixos salários, pois sabiam que os trabalhadores receberiam um complemento da paróquia dividido entre todos os contribuintes. $O$ fato de a administração da Lei dos Pobres conceder autonomia para as localidades significava que, nas paróquias rurais, onde os fazendeiros arrendatários eram a força preponderante dentro das sacristias ${ }^{13}$, se estabelecia uma relação promíscua entre esse grupo e os gestores locais, em detrimento dos pagadores de imposto que se dedicavam a outras atividades (Great Britain, 1906, p. 78-83). Esse ponto une a questão do auxílio à outra grande crítica dos comissários: a ausência de uma centralização administrativa referente aos pobres, deixando todo o poder decisório nas mãos de agentes locais despreparados, amadores, estúpidos, covardes e corruptos (Great Britain, 1906, p. 98-104). O fim do Sistema Speenhamland, bem como do Ato de Assentamentos, deveria, na opinião dos relatores, extinguir as amarras institucionais que prendiam a mão de obra ociosa às paróquias, fazendo com que esta naturalmente se dirigisse para onde houvesse procura.

Chadwick e Senior levantaram, na parte final do inquérito, um punhado de duas dezenas de recomendações para a realização de uma reforma geral no assistencialismo, que giravam em torno de três princípios essenciais, guardando vínculos intrínsecos entre si. O primeiro é a abolição de toda ajuda extramuros, que visava interromper o ciclo vicioso que contaminava os pobres e favorecia as classes fundiárias (Great Britain, 1906, p. 262). O segundo é a expansão das workhouses, que de-

\footnotetext{
13 As sacristias eram os espaços dentro da paróquia que reuniam os contribuintes locais para a votação de questões internas da localidade. O sistema de voto favorecia os fazendeiros ao conceder um peso proporcional à propriedade.
} 
veriam se converter na pedra fundamental da Lei dos Pobres reformada. Aqui observamos a influência mais explícita de Bentham. Embora as workhouses já existissem em número bem limitado, o enorme custo que essas casas representavam era demasiado alto para a grande maioria das paróquias, além de serem um desafio de gestão. Por isso, não eram vistas até então como uma alternativa viável pela administração pública. Para solucionar esse problema, a comissão sugeriu que as paróquias fossem reunidas em uniões administrativas, em que cada uma deveria contar com ao menos uma instituição desse tipo. As workhouses deveriam ser projetadas segundo princípios de ordem e disciplina.Tão logo adentrassem a instituição, as famílias deveriam ser divididas entre alas separadas conforme critérios de sexo, idade e estado de saúde. A rotina deveria ser rigorosa, com a imposição de tarefas a serem remuneradas por um valor abaixo do que o que se obteria no mercado fora do abrigo (Great Britain, 1906, p. 230-240). Com isso, os comissários estavam convencidos de que seria possível discernir mais facilmente o pobre realmente sem alternativas do vagabundo, pois apenas os primeiros aceitariam internar-se nessas condições, compondo aquilo que chamavam de "teste da workhouse":

Em tal casa ninguém entraria voluntariamente; trabalho, confinamento e disciplina iriam dissuadir o indolente e o vicioso, e nada além de extrema necessidade induzirá qualquer um a aceitar o consolo, que deve ser obtido pela renúncia de sua livre agência e pelo sacrifício de seus hábitos costumeiros e gratificações. Desse modo, o oficial paroquial, sendo provido de um teste infalível sobre a necessidade dos requerentes, é aliviado de sua mais penosa e dificil responsabilidade, ao passo que todos têm a satisfação de saber que, enquanto os necessitados são abundantemente socorridos, os fundos de caridade não são desperdiçados sobre ociosidade e fraude. (Great Britain, 1906, p. 270-271)

A terceira e última diretriz geral era a centralização administrativa. Propôs-se o estabelecimento de um órgão nacional com poderes para intervir sobre as localidades em qualquer assunto que dissesse respeito à Lei dos Pobres, estabelecendo uma pirâmide hierárquica entre essa entidade e as paróquias, tendo as uniões como elo intermediário (Great Britain, 1906, p. 217). Isso reduziria o controle das forças locais sobre as autoridades paroquianas, enfraquecendo a influência das elites fundiárias, 
bem como dos trabalhadores organizados, que podiam pressionar as classes médias na paróquia ou no município, como forma de incliná-las a gerir a assistência conforme julgassem mais vantajoso para seu próprio seguimento, que se via privado do acesso direto aos mecanismos decisórios do poder público ${ }^{14}$. O Parlamento prontamente acatou as recomendações principais do relatório, que serviram de base para a elaboração do Ato de Emenda de 1834, fundando o que passou a ser conhecido como a Nova Lei dos Pobres.

$\mathrm{O}$ ato de reforma vedou a ajuda extramuros, iniciou uma onda de construção e ampliação de workhouses e nomeou um comitê central para zelar pela aplicação da Nova Lei dos Pobres em todo o reino, a Comissão da Lei dos Pobres, na qual Chadwick ocupou o posto secundário de secretário, imediatamente inferior aos três comissários principais que ocupavam o topo da hierarquia. Entender as referências ideológicas dos reformadores é um passo importante para se analisar o caráter do novo modelo assistencialista. Embora muitos inimigos da reforma, entrincheirados em uma vigorosa rede de periódicos radicais de ampla circulação, tenham acusado a reforma de ser malthusiana, isso não parece verdade. É fato que a preocupação com os efeitos demográficos da Lei dos Pobres aparecem no relatório da comissão, através dos trechos recortados a partir das muitas entrevistas que os comissários assistentes obtiveram em suas visitas, mas esse mesmo elemento não transparece nos parágrafos propriamente escritos por Chadwick e Senior. Ambos manifestam grande apreensão com a degradação moral dos pobres induzida pela facilidade em se obter ajuda pública, mas não dão a entender que isso se traduz de forma automática em aumento demográfico. Poucos anos antes, o próprio Senior (1831) havia se notabilizado por um ensaio no qual desacreditava o princípio populacional malthusiano, o que inclusive lhe rendeu uma troca de cartas com Malthus debatendo suas discordâncias. Ele sustentou que as previsões malthusianas continham um pessimismo exagerado e que o quadro catastrófico só era realidade

14 Foster (2005) oferece uma análise bastante abrangente sobre o modo como os trabalhadores organizados eram capazes de influir sobre a gestão da Lei dos Pobres e outros assuntos das administrações locais. Empregando táticas que combinavam a legalidade com a clandestinidade, as estratégias incluíam, por exemplo, ameaçar com boicotes comerciantes locais, coagindo-os a votar conforme os interesses dos trabalhadores. 
quando os obstáculos positivos para o crescimento da população (ou seja, epidemias, fome e as demais mazelas que elevavam a mortalidade) predominavam sobre os obstáculos preventivos (matrimônio tardio, planejamento do número de filhos e tudo que atuava antes da concepção do bebê). Tal situação era típica de regiões pouco desenvolvidas, uma realidade distante da inglesa. Por si só, o aumento demográfico não era necessariamente negativo, sendo inclusive importante para fortalecer o crescimento econômico. Esse potencial positivo seria extraído conforme houvesse boas leis e um povo instruído intelectualmente e moralmente para desfrutar de suas possibilidades.

Chadwick, por sua vez, tinha como referência primordial o utilitarismo de Bentham, de quem fora amigo próximo e assistente pessoal. Sua prioridade era a gestão eficiente dos assuntos públicos, em que defendia uma presença mais forte do Estado na forma de uma defesa intransigente da centralização administrativa. $\mathrm{O}$ crescimento da população nunca esteve muito dentro de seu foco. $\mathrm{Na}$ verdade, ao longo de sua carreira como reformador da Lei dos Pobres e da saúde pública, Chadwick sempre encontrou no pensamento malthusiano um obstáculo enervante. Frustrava-o esbarrar constantemente com uma barreira de pessimismo que atribuía todos os problemas sociais ao aumento populacional em última instância, desacreditando seu esforço pessoal para encontrar soluções objetivas (Lewis, 1949, p. 30-32). É evidente que a carga negativa com a qual a Nova Lei dos Pobres revestia a figura do pobre era muito condizente com a forma como Malthus abordava essa categoria, mas esse retrato pejorativo esteve longe de ser um exclusivismo seu, estando tão difundido na primeira metade do século XIX, que esse estigma havia sido incorporado mesmo entre seus críticos.

Pode-se argumentar que a postura centralizadora e intervencionista adotada pelos reformistas feria princípios do laissez-faire, como colocou Himmelfarb (1988, p. 193-198) em seu trabalho sobre a concepção da pobreza na Inglaterra da Revolução Industrial. A autora considera que o princípio norteador da reforma não foi propriamente a propagação de um liberalismo econômico, mas, sim, a "despauperização", isto é, a necessidade de acabar com um estado de miséria que contradizia o discurso de progresso econômico associado à industrialização. O caminho para tal seria a adoção da workhouse e a filtragem que esta faria entre pobres honestos e viciosos. Essa interpretação parece tomar forma 
por conteúdo, dando a entender que a defesa de um Estado fortalecido seria incompatível com o conceito de livre mercado associado aos objetivos do programa reformista. Como já mencionado, a centralização foi uma forma de esvaziar a capacidade de tomada de decisão das localidades, em que os interesses contrários à mudança na Lei dos Pobres conseguiam agir mais diretamente. Uma economia em que o preço da força de trabalho seria regulado unicamente pelo mercado não era (e jamais veio a ser) um ideal que se concretizaria espontaneamente.

A capacidade dos idealizadores da Nova Lei dos Pobres e os demais detratores do modelo anterior de estabelecerem sua própria narrativa mostraram-se eficientes ao ponto de repercutir longamente na historiografia. Mesmo entre críticos da reforma, a noção de que os abonos extramuros estavam desequilibrando a economia rural desde o século XIX foi tomada como um consenso. Foi preciso uma perspectiva revisionista, iniciada por Blaug (1963) e aprimorada por Boyer (2006), para superar essa visão. Para esses autores, o impacto real do sistema era limitado demais para ser responsabilizado por uma crise agrícola, e seu efeito foi mais provavelmente de elevar os salários após as guerras do que rebaixá-los, contribuindo para a recuperação da economia. Observou-se que, nos 18 condados onde o Sistema Speenhamland foi posto em prática, todos rurais, o abono per capita era sensivelmente maior do que nos condados que não o fizeram. Mas, quanto ao padrão de flutuação desses valores, os 2 grupos apresentavam um comportamento semelhante, evidenciando uma economia inter-relacionada, em que as causas que aliviam ou afligem a pobreza repercutem nacionalmente (Blaug, 1963, p. 164-167, 181).

Destaca-se que, nas zonas rurais, o ciclo da procura de trabalho apresenta particularidades próprias do cultivo de cereais, especialmente do trigo, a cultura mais importante na época. Se, nos meses das semeaduras e colheitas, a procura por trabalho era intensa, no resto do ano essa demanda era bem mais baixa. O desemprego sazonal fazia parte do mundo do trabalho rural, com essa situação sendo agravada pela industrialização, que introduziu competidores desiguais para alguns setores das antigas manufaturas domésticas, restringindo ainda mais as opções de ocupação produtiva para os que encontravam dificuldade em se empregar (Blaug, 1963, p. 161-164).A concessão de abonos em dinheiro vivo, uma prática que já vinha se expandindo décadas antes do Sistema 
Speenhamland, surgia onde o rendimento anual médio dos trabalhadores era insustentavelmente baixo, sendo por isso consequência e não causa do empobrecimento (Boyer, 2006,p. 45-52).É interessante notar também que a campanha contra o auxílio extramuros era direcionada para a realidade rural do Sul e do Leste da Inglaterra, mas não para o Norte e Oeste mais urbanizados, onde o pagamento de abonos permaneceu longamente após 1834. Como o trabalho urbano oferecia mais perspectivas de emprego no decorrer do ano, aceitava-se que essa forma de pagamento era mais eficiente para socorrer a pobreza em surtos momentâneos de desemprego, sem que isso se convertesse em um subsídio regular de salários. Além disso, o fornecimento de cuidados médicos ao custeio da paróquia continuou recorrente, mesmo sendo considerada uma prática de cuidados extramuros (Green, 2010, p. 15).

Apesar dos massivos investimentos públicos em workhouses, que até a década de 1860 receberam muito mais verba do que a educação pública, por exemplo, as práticas extramuros continuaram a ser, nacionalmente, responsáveis pela maior parte dos gastos com a pobreza (três vezes mais do que os cuidados intramuros) nos anos que se seguiram à reforma (Green, 2010, p. 128-134, 194-196). Novas legislações, visando coibir as despesas com pobres não internados, apareceram em 1842, 1844 e 1852, e uma nova cruzada social contra a assistência paroquial surgiu no fim da década de 1860 , resgatando a ideia de que a caridade privada voluntária seria uma alternativa mais interessante do que o sistema público (MacKinnon, 1987). O órgão central da Lei dos Pobres teve de conviver em perpétua queda de braço com os administradores paroquiais, que insistiam que as diretrizes impostas pela Nova Lei dos Pobres não eram viáveis. $\mathrm{O}$ fato de que o discurso reformista optou por apoiar-se em distorções da realidade para justificar-se resultou no custo prático de que este não estaria talhado para o plano concreto. A imposição de um liberalismo bruto simplesmente não era condizente com os problemas reais da sociedade inglesa.

\section{Conclusão}

Os entraves que se colocaram no caminho da administração da Nova Lei dos Pobres após a instituição da reforma, inviabilizando que ela 
fosse executada nos moldes em que fora planejada, não significam que a iniciativa tenha sido um fracasso. Politicamente, tratou-se de uma vitória importante do ideal de economia de mercado, para o qual o preço da força de trabalho deveria ser regulado organicamente pela relação entre oferta e demanda.A aprovação da reforma também marcou um momento de demonstração de força política dos grupos econômicos associados à indústria, demonstrando que, mesmo carecendo de certa organização interna, já contavam com apoio decisivo de uma rede de agentes entre a classe média. Estes, na condição de intelectuais mobilizados em favor de políticas reformistas, eram capazes de fazer frente a poderes mais tradicionais em questões de alta relevância socioeconômica. Entre esses homens, críticos ferrenhos dos socorros extramuros, encontramos nomes que se destacaram na vida pública, como Kay-Shuttleworth, Senior e Chadwick, que se envolveriam a partir dali em questões diversificadas, como o sistema educacional, a legislação fabril e a reforma sanitária. Em cada um desses campos, esses homens levam perspectivas que orientaram a reforma de 1834: a preocupação em se desarmar as bases do radicalismo popular, a moralização da classe trabalhadora pelo trabalho e o doutrinamento, a intervenção centralizadora do Estado quando os interesses de poderes locais comprometiam um ideal de organização a ser instituído nacionalmente, a busca por soluções que favorecessem (ou ao menos não comprometessem) o fluxo comercial e o ritmo da acumulação de capital industrial. Tecia-se uma rede que articulava ação parlamentar, iniciativas privadas, gestores e conselheiros públicos, dentro da qual essa intelectualidade apresentava papel fundamental, interconectando os atores, atuando como porta-voz e transformando as aspirações econômicas da burguesia urbana comercial e industrialista em ideias mais encorpadas, capazes de serem assimiladas na condição de políticas públicas. É por meio desse processo de convencimento que o interesse de um setor econômico proeminente, mas ainda carente de hegemonia cultural e ideológica, desenvolve-se de modo a ser apresentado como um interesse mais geral da sociedade, um plano nacional. Fazia-se necessário, para tal, o controle das narrativas, como se fez ao retratar a Lei dos Pobres em um tom incongruente com o da realidade. O fruto desse esforço é observável com maior clareza alguns anos depois, na organização da Liga Antileis dos Cereais, uma entidade de classe estruturada conscientemente nesse sentido. Quando 
esta atinge seu objetivo em 1846, o espírito reformista burguês dá lugar a um tom novamente mais conciliador com a nobreza agrária. Mas a reaproximação se daria num quadro político distinto do anterior a 1832, com uma alta burguesia mais capacitada a exercer seu poder socioeconômico de modo a afirmar seu papel pertencente à esfera dominante, dentro de uma sociedade reformada para favorecer essa atuação.

\section{Referências bibliográficas}

ANDERSON, Perry. Origins of the present crisis. New Left Review, n. 23, p. 26-53, jan.-fev. 1964.

BEIER, Lucinda A. The problem of the poor in Tudor and early Stuart England. New York: Metheun, 2004.

BENTHAM, Jeremy. An introduction to the principles of morals and legislation. London: W. Pickering, 1823. Disponível em <https://books.google.com.br/books/about/ An_Introduction_to_the_Principles_of_Morhtml?id=qWcAAAAAMAAJ\&redir_ esc $=y>$. Acesso em 8/1/2016.

BERG, Maxine. The machinery question and the making of political economy, 1815-1848. Cambridge: Cambridge University Press, 1982.

BLAUG, Mark. The myth of the old Poor Law and the making of the New. The Journal of Economic History, v. 23, n. 2, p. 151-184, jun. 1963.

BOYER, George. English Poor Laws. EH.Net Enclycopedia, 2002. Disponível em $<$ https://eh.net/encyclopedia/english-poor-laws/>. Acesso em 11/10/2017.

BOYER, George. An economic history of the English Poor Law, 1750-1850. Cambridge: Cambridge University Press, 2006.

CHARLESWORTH, Lorie. Welfare's forgotten past: a socio-legal history of the Poor Law. New York: Routledge, 2010.

ENGELS, F. Condition of the working class in England. [S.1.]: Marx/Engels Internet archive, 2010. Disponível em < https://ww w.marxists.org/archive/marx/works/download/ pdf/condition-working-class-england.pdf $>$. Acesso em 3/4/2017.

FOSTER, J. Class struggle and the Industrial Revolution. London: Metheun \& Co, 2005.

GASKELL, P. The manufacturing population of England. London: Baldwin and Cradock, 1833. Disponível em <https://archive.org/details/manufacturingpop00gaskuoft>. Acesso em 8/3/2016.

GEREMEK, Bronislaw. A piedade e a forca: história da miséria e da caridade na Europa. Lisboa:Terramar, 1986.

GREAT Britain. Poor Law Comissioners. Poor Law Commissioners' report of 1834- copy of the report made in 1834 by the commissioners for inquiring into the administration and practical operation of the Poor Laws. London: Darling \& Son, 1906. Disponível em <http://lf-oll.s3.amazonaws.com/titles/1461/0169_Bk.pdf>. Acesso em 21/5/2018. 
GREEN, David. R. Pauper capital: London and the Poor Law, 1790-1870. Surrey:Ashgate, 2010.

HIMMELFARB, Gertrude. La idea de la pobreza: Inglaterra a principios de la época industrial. México: Fondo de Cultura Económica, 1988.

HINDLE, S. On the parish? The micro-politics of poor relief in rural England, 15501750. Oxford: Oxford University Press, 2004.

JONES, Gareth Stedman. An end to poverty? A historical debate. New York: Columbia University Press, 2004.

KAY-SHUTTLEWORTH, J. P. The moral and physical condition of the working classes employed in the cotton manufacture in Manchester. London: Harrison \& Crosfield, 1832. Disponível em < https://archive.org/details/moralphysicalcon00 kaysuoft>.Acesso em 13/4/2017.

KING, Steven. Making the most opportunity: the economy of makeshifts in the early modern north. In: KING, Steven;TOMKINS, Alannah (org.). The poor in England, 1700-1850. Manchester: Manchester University, 2003.

KIRBY, Peter. Child labour in Britain, 1750-1870. China: Palgrave Macmilliam, 2003.

LEWIS, R.A. Edwin Chadwick and the Public Health Movement, 1832-1854. Birmingham: University of Birmingham, 1949, p. 206 (Tese de Doutorado em História). Disponível em <http://etheses.bham.ac.uk/4589/1/Lewi s1949PhD1.pdf>. Acesso em $11 / 1 / 2017$.

MACKINNON, Mary. English Poor Law policy and the crusade against outrelief. The Journal of Economic History, v. 47, n. 3, p. 603-625, set. 1987.

MALTHUS, Thomas. An essay on the principle of population. [S.1.]: Eletronic Scholarly Publishing Project, 1998. Disponível em <http://www.esp.org/books/malthus/ population/malthus.pdf $>$. Acesso em 11/10/2017.

MANDEVILLE, Bernard. The fable of the bees. New York: Capricorn Books, 1962.

MARX, K. Capital - a critical of political economy.V. 1. [S.1.]: Marx/Engels Internet archive, 2015. Disponível em < https://www.marxists.org/archive/marx/works/ download/pdf/Capital-Volume-I.pdf>. Acesso em 26/2/2018.

PATRIQUIN, L. Agrarian capitalism and poor relief in England, 1500-1860. Basingstoke: Palgrave Macmilliam, 2007.

RICARDO, David. On the principles of political economy and taxation. 3. ed., 1821. Disponível em <http://www.econlib.org/library/Ricardo/ricP.html>. Acesso em 27/9/2015.

SENIOR, William Nassau. Two lectures on population. London: Saunders and Otley, 1831. Disponível em <http://oll.libertyfund.org/titles/senior-two-lectures-on-population $>$. Acesso em 30/4/2016.

SMITH,Adam. An inquiry into the nature and causes of the wealth of nations. [S.1.]: Metalibri, 2007._Disponível_em_<http://www.ibiblio.org/ml/libri/s/SmithA_ WealthNations_p.pdf $>$. Acesso em 2/10/2016.

TAYLOR, W. C. Factories and the factory system. London: Palmer \& Clayton, 1844. Disponível em <https://books.google.com.br/books/about/Factories_and_the_ Factory_System.html?id=dXs4AAAAMAAJ\&redir_esc=y>.Acesso em 18/5/2016. 
THOMPSON, E. P. The making of the English working class. New York:Vintage Books, 1996.

THOMPSON, E. P. Folclore, antropologia e história social. In: NEGRO, Antonio Luigi; SILVA, Sergio (org.). As peculiaridades dos ingleses - e outros artigos. Campinas: UNICAMP, 2001.

TIERNEY, Brian. Medieval Poor Laws - a sketch of canonical theory and its application in England. Los Angeles: University of California, 1959.

TOWNSEND, Joseph. A dissertation on the Poor Laws. London: Ridgways, 1817. Disponível em <https://books.google.com.br/books/about/A_dissertation_on_the_ poor_laws.html?id=PZJPAAAAYAAJ\&redir_esc=y $>$. Acesso em 27/12/2015.

VOTH, Hans-Joachim. Living standards and the urban environment. In: FLOUD, Roderick;JOHNSON, Paul (orgs.). The Cambridge economic history of modern Britain. V. 1. Cambridge: Cambridge University Press, 2006.

WOOD, Ellen Melksins. A origem do capitalismo. Trad.Vera Ribeiro. Rio de Janeiro: Jorge Zahar, 2001.

WORDIE, J. R. The chronology of English enclosure, 1500-1914. The Economic History Review, New Series, v. 36, n. 4, p. 483-505, nov. 1983. 